\title{
Reconnaissance study on sulfur isotopic ratios of lead-zinc ores from North Vietnam
}

\begin{abstract}
Shunso Ishihara ${ }^{1, *}$, Tuan Anh $\operatorname{Tran}^{2}$ and Kezhang Qin ${ }^{3}$
Shunso Ishihara, Tuan Anh Tran and Kezhang Qin (2010) Reconnaissance study on sulfur isotopic ratios of lead-zinc ores from North Vietnam. Bull. Geol. Surv. Japan, vol.61 (11/12), p.485-488, 2 figs, 1 table.

Abstract: Sulfur isotopic ratios were studied on representative lead-zinc feeding ores, zinc concentrates and lead concentrates from selected mines in North Vietnam. These sulfides from the Triassic rhyolite hosted ore deposits have $\delta^{34} \mathrm{~S}$ values of +3.4 to $+4.7 \%$, while those from purely Paleozoic sedimentary host rocks are slightly heavier, ranging from +4.4 to $+8.2 \%$. No $\delta^{34} \mathrm{~S}$ values similar to those of the Mississippi Valley-type lead-zinc ores have been found. Lead concentrates are always smaller than zinc concentrates in the $\delta{ }^{34} \mathrm{~S}$ values. Two very depleted $\delta{ }^{34} \mathrm{~S}$ values were found in the Cho Dien mine area where detailed isotopic study is necessary.
\end{abstract}

Keywords: Lead-zinc ores, concentrates, Paleozoic sediments, Triassic rhyolite, $\delta{ }^{34} \mathrm{~S}$ value

\section{Introduction}

Sulfur isotopic ratios of base metal ore deposits are very important tool to understand provenance of the ore sulfur of these deposits. In the Japanese Islands, sulfur of the late Mesozoic to Tertiary vein- and skarn-type deposits show corresponding $\delta^{34} \mathrm{~S}$ values of the ores to those of the related granitic rocks (Sasaki and Ishihara, 1979; 1980; Shimazaki, 1985; Ishihara and Sasaki, 2002). In North Vietnam, many small to middle size lead- zinc ore deposits occur mostly in Paleozoic sedimentary terrain to the north of the capital Ha Noi, and also one small deposit in Triassic rhyolites to the northeast of Ha Giang, very close to the Chinese border (Fig. 1). They have interesting chemical characteristics rich in indium, arsenic and rare earth elements (Ishihara et al., 2010a, b).

The sediments hosted ore deposits occur in Cambrian to Carboniferous sedimentary rocks rich in carbonates, which are intruded by Triassic granitic rocks. Some of the ore deposits in the Cho Don and Cho Dien areas, Bac Kan Province, could have been related to ore fluids liberated from the Triassic granitoids (i.e., Cho Dien and Na Bop type, Ishihara et al., 2010a, b). On the contrary, the ore deposits occurring in purely sedimentary rocks in the Thai Nguyen Province (Lang Hich type) may be originated in the ore fluids of sedimentary origin. There are lead-dominant base metal deposits in the Triassic rhyolites (Na Son type) in Ha Giang Province, which should have been formed by post-extrusive fluid activities of the host rhyolitic rocks.

In order to understand characteristics and origin of sulfur of these ores, a reconnaissance study was made on sulfur isotopes of composite ores, and zinc and lead concentrates of the major ore deposits, whose locations are shown in Fig. 1. Geology and chemical characteristics of the studied ore deposits are described separately in Ishihara et al. (2010a, b).

Sulfur isotopes were measured at the Institute of Geology and Geophysics, Chinese Academy of Sciences, by using a conventional off-line method (Robinson and Kusakabe, 1975). Approximately $15 \mathrm{mg}$ of sulfides was homogenized with $150 \mathrm{mg}$ of $\mathrm{Cu}_{2} \mathrm{O}$, combusted at $1050{ }^{\circ} \mathrm{C}$ for $15 \mathrm{~min}$ under vacuum for a quantitative conversion to sulfur dioxide $\left(\mathrm{SO}_{2}\right)$ and analyzed for sulfur isotope composition on a Finnigan DELTA S gas source mass spectrometer. Sulfur isotope ratios are expressed as per mil (\%o) deviations from the sulfur isotope composition of the Cañon Diablo Troilite using the conventional delta $\left(\delta{ }^{34} \mathrm{~S}\right)$ notation within precision of $0.004 \%$. Sulfur isotope results are generally reproducible within $\pm 0.3 \%$ (accuracy).

\footnotetext{
${ }^{1}$ National Institute of Advanced Industrial Science and Technology (AIST)

${ }^{2}$ Institute of Geological Sciences, Vietnamese Academy of Science and Technology, Hanoi, Vietnam

${ }^{3}$ Institute of Geology and Geophysics, Chinese Academy of Sciences, Beijing, China

* Corresponding author: S. ISHIHARA, Central 7, 1-1-1 Higashi, Tsukuba, Ibaraki 305-8567, Japan. Email: s-ishihara@aist.go.jp
} 


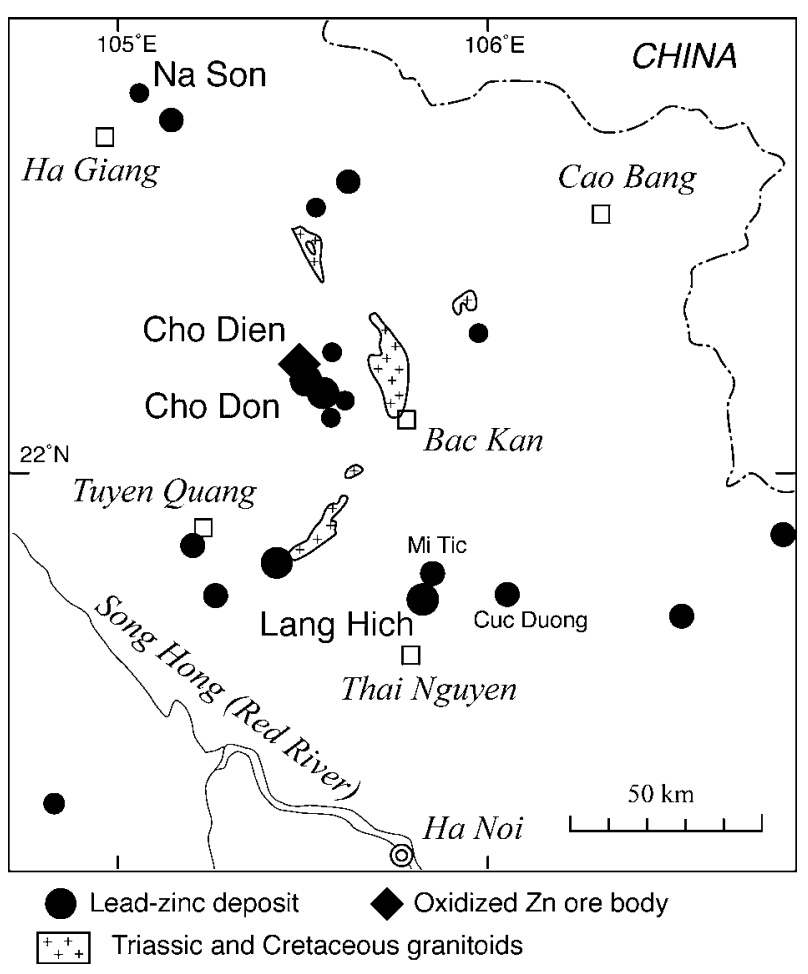

Fig. 1 Location map of the studied ore deposits in North Vietnam. Originally from ESCAP (1990), partly modified. Size of lead-zinc deposits implies relative size difference of the ore deposits.

\section{Analytical results}

Analytical results are shown in Table 1 . An average of two feeding ores at the $\mathrm{Na}$ Son mine give $\delta$ ${ }^{34} \mathrm{~S}$ values of +3.4 and $+4.0 \%$. Zinc concentrates are heavier, $+4.7 \% \circ \delta^{34} \mathrm{~S}$, than the feeding ores. Lead concentrates are +4.1 and $+4.1 \% \delta^{34} \mathrm{~S}$; thus lower than the values of the zinc concentrates (Fig. 2).

Sulfur isotopic ratios are most variable in the ore deposits of Cho Don and Cho Dien areas, where they occur in sedimentary rocks intruded by granitic and syenitic rocks. Only one composite sample available from $\mathrm{Pu}$ Sap mine is $+4.5 \% \circ \delta^{34} \mathrm{~S}$, which is slightly higher than $\delta{ }^{34} \mathrm{~S}$ values of the Na Son mine. Zinc concentrates show the $\delta{ }^{34} \mathrm{~S}$ values ranging from +6.9 to $+7.5 \%$, which are much higher than $\delta^{34} \mathrm{~S}$ values of the $\mathrm{Na}$ Son mine. On the contrary, zinc and lead concentrates from Cho Dien mine have very low $\delta{ }^{34} \mathrm{~S}$ values of $+0.6 \%$ and $+0.0 \%$, respectively.

Lead-zinc deposits occurring in purely sedimentary terrains around the Thai Nguyen Province have relatively high $\delta{ }^{34} \mathrm{~S}$ values. The feeding ores range from +6.3 to $+8.2 \%$. Zinc concentrates varies from +7.2 to $+7.9 \%$, while lead concentrates are lower, as +4.4 to $+6.4 \%$ (Table 1 ). Again, the lead concentrates are lower than zinc concentrates in the $\delta{ }^{34} \mathrm{~S}$ values (Fig. 2).

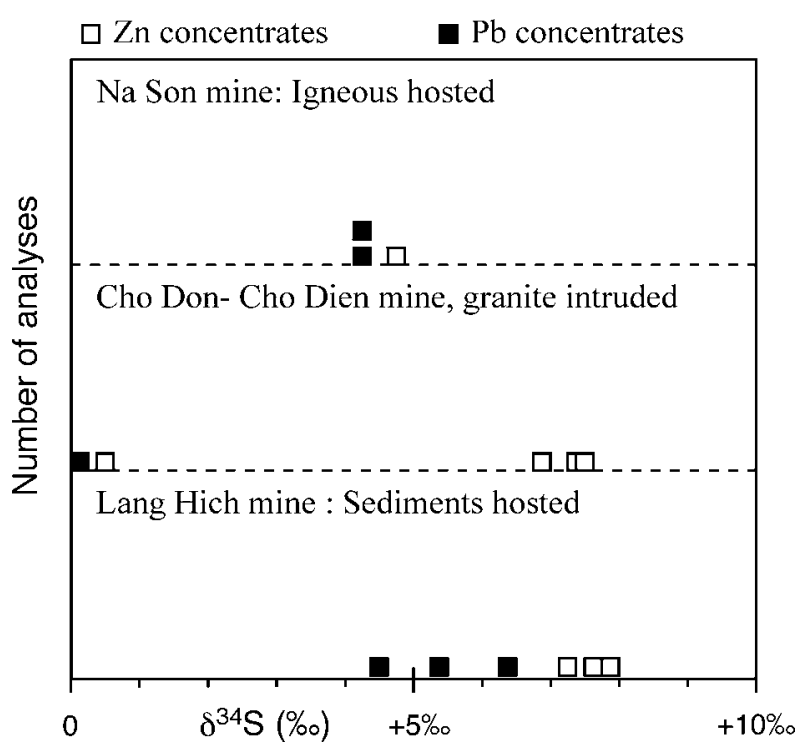

Fig. 2 Graphic presentation of the obtained $\delta{ }^{34} \mathrm{~S}$ values of zinc and lead concentrates from North Vietnam.

\section{Discussions on source of the ore sulfur}

Sulfur isotopic ratios of sulfides in sedimentary terrain are first controlled by $\delta{ }^{34} \mathrm{~S}$ values of sea water (Claypool et al., 1980), which are known to vary widely by coexisting sulfate values. The highest value is known in the early Cambrian sulfate as $+32 \%$, while the lowest is seen at the Triassic-Permian sulfate around $+12 \%$. The sulfate values vary from $+15 \%$ o to +32 $\%$ in Cambrian to Carboniferous rocks, which are most abundant in the northern Vietnam.

Structurally substituted sulfate (SSS) of the Cambro-Ordovician carbonate rocks in South Korea vary from +25.9 to $+45.2 \%$, and the average is + $33.6 \%$ (Ishihara et al., 2002a). This sedimentary sulfur may reflect on later igneous mineralizations through interaction between the carbonates and granitic magmas (Ishihara et al., 2002a, b). Sulfur isotopic ratios of the feeding ores from the Lang Hich mine range from +6.3 to $+8.2 \%$ o, much smaller than the SSS values.

For the proposal of the Mississippi Valley-type ore geneses (see, Ishihara et al., 2010a), sulfur isotopic values of sulfides need to be compared to those of typical ores in the Mississippi Valley region. Shelton et al. (2009) reported that the Cambro- Ordovician Mississippi Valley type ore deposits in Southeast Missouri, U.S.A., have a range from +0.5 to $+15.3 \%$ o and the average of $+11.0 \%$ ( $n=28)$. No such large variation and heavy isotopic values were observed in the sulfide ores and concentrates from the Lang Hich deposits located in carbonate-rich sedimentary terrains in North Vietnam.

In the rhyolite-hosted $\mathrm{Na}$ Son deposits, a narrow range $\left(+3.4\right.$ to $+4.0 \%$ ) of the $\delta{ }^{34} \mathrm{~S}$ values on the 
Table 1 Sulfur isotopic result on the lead-zinc ores and concentrates from North Vietnam.

\begin{tabular}{|c|c|c|}
\hline Sample No. & Ore types & $\delta^{34} S(\%)$ \\
\hline \multicolumn{3}{|c|}{ Na Son mine, Ha Giang Province } \\
\hline $2010-63$ & Feeding ore & +3.4 \\
\hline $2010-64$ & Zn concentrates & +4.7 \\
\hline $2010-65$ & $\mathrm{~Pb}$ concentrates & +4.1 \\
\hline $2010-67$ & Feeding ore & +4.0 \\
\hline $2010-68$ & $\mathrm{~Pb}$ concentrates & +4.1 \\
\hline \multicolumn{3}{|l|}{ Cho Don, Bac Kan Province } \\
\hline SI-0407a (Na Tum) & Zn concentrates & +7.5 \\
\hline SI-0407b (Na Tum) & Zn concentrates & +7.5 \\
\hline SI-0401 (Pu Sap) & Composite sample & +4.5 \\
\hline SI-0404 (Na Bop+Pu Sap) & $\mathrm{Zn}$ concentrates & +6.9 \\
\hline \multicolumn{3}{|l|}{ Cho Dien, Bac Kan Province } \\
\hline SI-1708 & Zn concentrates & +0.6 \\
\hline SI-1709 & $\mathrm{Pb}$ concentrates & +0.0 \\
\hline \multicolumn{3}{|c|}{ Lang Hich mine, Thai Nguyen Province } \\
\hline $2010-42$ & Feeding ore & +6.3 \\
\hline $2010-43$ & Zn concentrates & +7.7 \\
\hline $2010-44$ & $\mathrm{~Pb}$ concentrates & +6.4 \\
\hline $2010-54$ & Feeding ore & +8.2 \\
\hline $2010-55$ & Zn concentrates & +7.2 \\
\hline $2010-56$ & $\mathrm{~Pb}$ concentrates & +4.4 \\
\hline SI-0301 & Zn concentrates & +7.9 \\
\hline SI-0303 & $\mathrm{Pb}$ concentrates & +5.3 \\
\hline
\end{tabular}

feeding samples is observed (Table 1). Empirically speaking, ore sulfides are generally ca. 2 per mil lower than the related rock sulfides in granitic terrains (Ishihara and Sasaki, 2002). With this regards, 5-6 per mil could be assumed for the host rhyolitic magma, which is similar to the values of the magnetite-series granitoids in the Japanese Islands (Sasaki and Ishihara, 1979). The feeding ore values of +6.3 and $+8.2 \%$ in the Lang Hich deposits are more close to the felsic magmatic value than the SSS values of the host carbonate rocks.

Largest variation observed on the $\delta{ }^{34} \mathrm{~S}$ values is those on the Bac Kan Province, because of two depleted $\delta{ }^{34} \mathrm{~S}$ values in the Cho Dien mine. Here, the zinc concentrates of the Cho Don area have similar $\delta{ }^{34} \mathrm{~S}$ values to those of the Lang Hich mine, but one set of lead and zinc concentrates of the Cho Dien area are very depleted in ${ }^{34} \mathrm{~S}$. Exact location of these concentrates is not known, because ores from different locality are often mixed before the flotation in this mine area. Geological condition to lower the $\delta{ }^{34} \mathrm{~S}$ values may be (1) mixture of ${ }^{34} \mathrm{~S}$-depleted sulfur in the source area of the hydrothermal ore fluids, and/or (2) sulfate extracted prior to the sulfide precipitation during the hydrothermal mineralizations. Addition of ${ }^{34} \mathrm{~S}$ depleted sulfur like the one in black shale to the source fluids is most probable, yet we need further detailed sampling and microscopic and isotopic studies on representative ore deposits in the Cho Dien mine area.

\section{Concluding remarks}

Reconnaissance study was made on representative lead-zinc ore deposits occurring in three different host rock environments: (1) Triassic rhyolite hosted, (2) Paleozoic sediments hosted, and (3) similar Paleozoic sedimentary rocks intruded by Triassic granite. The rhyolite hosted ones have a low range of +3.4 and $+4.7 \%$ o, and sediments-hosted ones vary from +4.4 to $+8.2 \%$. No ${ }^{34} \mathrm{~S}$-enriched values similar to those of the Mississippi Valley type have been observed in North Vietnam.

Further detailed study is necessary on the ores with nearly $0 \%$ o $\delta^{34} \mathrm{~S}$. 


\section{References}

Claypool, G. E., Holser, W., Kaplan, I. R., Sakai, H. and Zak, I (1980) The age curves of sulfur and oxygen isotopes in marine sulfate and their mutual interpretation. Chemical Geol., 28, 199-260.

ESCAP (1990) Atlas of mineral resources of the ESCAP region vol. 6, Viet Nam. Explanatory Brochure and maps, $124 \mathrm{p}$.

Ishihara, S. and Sasaki, A. (2002) Paired sulfur isotopic belts: Late Cretaceous- Paleogene ore deposits of Southwest Japan. Bull. Geol. Surv. Japan, 53, 461477.

Ishihara, S., Jin, M. S. and Kajiwara, Y. (2002a) Sulfur content and isotopic ratio of Cambro-Ordovician carbonate rocks from South Korea. A possible source for Mesozoic magmatic-hydrothermal ore sulfur. Resource Geology, 52, 41-48.

Ishihara, S., Kajiwara, Y. and Jin, M. S. (2002b) Possible carbonate origin of ore sulfur from Geumseong Mo deposits, South Korea. Resource Geol., 52, 279-282.

Ishihara, S., Wang, P. A., Watanabe, Y. and Kajiwara, Y. (2003) Origin of sulfur in some magmatichydrothermal ore deposits of South China. Bull. Geol. Surv. Japan, 54, 161-169.

Ishihara, S., Tran, T-A., Can, P-N. and Dung, P. (2010a) Chemical characteristics of $\mathrm{Pb}-\mathrm{Zn}$ ores and their tailings in the northern Vietnam. Shigen-Chishitsu, 60, 93-102 (in Japanese with English abstract).
Ishihara, S., Tran, T-A., Watanabe, Y. and Tran, T-H. (2010b) Chemical characteristics of lead-zinc ores from North Vietnam, with a special attention to the indium content. Bull. Geol. Surv. Japan, 61, 307323.

Robinson, B. W. and Kusakabe, M. (1975) Quantitative preparation of sulfur dioxide, for ${ }^{34} \mathrm{~S} /{ }^{32} \mathrm{~S}$ analyses, from sulfides by combustion with cuprous oxide. Analyt. Chem. 47, 1179-1181.

Sasaki, A. and Ishihara, S. (1979) Sulfur isotopic composition of the magnetite-series and ilmeniteseries granitoids in Japan. Contrib. Mineral. Petrol. 68, 107-115.

Sasaki, A. and Ishihara, S. (1980) Sulfur isotope characteristics of granitoids and related mineral deposits in Japan. Proc. Fifth Quad. IAGOD Sym., Schweizerbart'sche Verlagsbuchhandlung, Stuttgart, 325-335.

Schelton, K. L., Gregg, J. M. and Johnson, A. W. (2009) Replacement dolomites and ore sulfides as recorders of multiple fluids and fluid sources in the Southeast Missouri Mississippi Valley-type district: Halogen- ${ }^{87} \mathrm{Sr} /{ }^{86} \mathrm{Sr}-\delta{ }^{18} \mathrm{O}-\delta{ }^{34} \mathrm{~S}$ systematics in the Bonneterre Dolomite. Econ. Geol., 104, 733-748.

Shimazaki, H. (1985) Regional variation of isotope composition of hydrothermal ore sulfur in Japan. Jour. Fac. Sci., Univ. Tokyo, Sect. 2, 21, 81-100.

Received July 21, 2010

Accepted September 6, 2010

\title{
北部ベトナムからの鉛亜鉛鉱石の硫黄同位体比の予察的研究
}

\author{
石原舜三・Tuan Anh Tran・秦＼cjkstart克章 \\ 要 旨
}

北部ベトナム産の代表的鉛亜鉛鉱床の供給鉱石・亜鉛精鉱・鉛精鉱の硫黄同位体比 $\left(\delta^{34} \mathrm{~S}\right)$ を測定した。三畳紀流紋 岩中の鉛亜鉛鉱床産試料は+ $3.4 \sim+4.7 \%$ であり，古生代堆積岩類中の鉱石試料はやや重い+ $4.4 \sim+8.2 \%$ を示し た.ミシシピーバレー型鉛亜鉛鉱石に相当する重い值は得られなかった. 鉛精鉱は亜鉛精鉱よりも常に軽い值を示した. Cho Dien 鉱山からの鉛精鉱・亜鉛精鉱は著しく低い值を示し，それらの原鉱の硫黄同位体比を精査する必要がある。 